\title{
Perceived Competence in Detecting Mis- and Disinformation Online: Reconsidering the Third Person Effect
}

\section{Asuman Kutlu}

\begin{abstract}
The third person effect coined by Davison, provides a different perspective from media effect theories as it mainly deals with beliefs about media effects rather than its direct influence on individuals. The literature on TPE has demonstrated a broad perspective in exploring perceptual bias in various media contexts as well as conditions to magnify TPE. The issue of digital disinformation has increased the number of studies as it has provided a different perspective in context of the third person effect. The threat caused by COVID-19 has led an increase in health news consumption causing a wide spread of mis/disinformation about the origin, prevention and treatment of the pandemic. Considering source credibility as a moderator in testing TPE hypothesis, people will likely to think that mis-and disinformation online will have a greater effect on others and may depend on their perceived competence in spotting mis- and disinformation online when judging its effect on oneself and others. Therefore, the research aims at exploring the way individuals perceive the effects of health-related mis/disinformation and the possible variables influencing TPE.A survey-based study of 767 Turkish internet users was conducted in January 2021. Paired simple T-test to explore third person effect and hierarchical regression analysis to investigate factors associated with TPE were performed. Results revealed that biased third-person effects existed regarding health related mis/disinformation online and perceived competence to detect mis/disinformation online and exposure to digital mis/disinformation were the significant predictors of TPE.
\end{abstract}

Keywords: Third-Person Effect, Misinformation, Disinformation, Digital Media, Health News

\author{
ASUMAN KUTLU \\ Asst. Prof. \\ Beykent University \\ asumank@beykent.edu.tr \\ ORCID ID: 0000-0003-2770-3008
}

SELÇUK ILETIŞIM DERGISI 2021; 14(2): 514-528

doi: 10.18094/ JOSC.881441

Geliş Tarihi: 16.02.2021 Kabul Tarihi: 10.03.2021 Yayın Tarihi: 25.04.2021 


\title{
Çevrimiçi Mez/Dezenformasyonun
}

Tespit Edilmesinde Algılanan

Yetkinlik: Üçüncü Kişi Etkisini

Yeniden Düşünme

SELÇUK ILETIŞIM

DERGISI 2021;

14(2): 514-528

doi: 10.18094/ JOSC.881441

[\$?

SYEL데K

ILETISTM

\section{Asuman Kutlu}

ÖZ

Davison tarafından alanyazına kazandırılan üçüncü kişi etkisi, medyanın kişiler üzerindeki doğrudan etkisi yerine medyanın algılanan etkilerine odaklanarak medya etki teorilerinden farklı bir bakış açısı sağlamaktadır. Literatürde üçüncü kişi etkisi farklı kitle iletişim araçlarında algısal yanlıı̆̆ı ve bu yanlılığı artıran etkenleri de tartışacak şekilde oldukça geniş bir yelpazede ele alınmaktadır. Dijital dezenformasyon konusu, üçüncü kişi teorisinin yeni bir bağlamda ele alınmasını sağlayarak yapılan çalışmaları artırmıştır. KOVID-19 salgının yarattığı tehditle birlikte sağlık haberi tüketiminin artması, pandeminin nedeni, önlenmesi ve tedavisine ilişkin mez/dezenformasyonun geniş çapta yayılmasını beraberinde getirmiştir. Kaynak güvenirliği, üçüncü kişi hipotezinin sınanmasında bir değişken olarak ele alındığında, kişilerin çevrimiçi mez/dezenformasyonun diğerlerinin üzerinde daha güçlü bir etkiye sahip olduğunu düşünme eğiliminde olacağı ve kendileri ve diğerleri üzerinde oluşan etkiyi değerlendirirken, çevrimiçi mez/dezenformasyonu tespit edebilmede kendilerine duydukları güvenin etkili olabileceği düşünülmektedir. Bu nedenle araştırma, kişilerin sağlık konulu mez/dezenformasyonun etkilerine ilişkin algısını ve üçüncü kişi etkisini etkileyen olası değişkenleri ortaya çıkarmayı amaçlamaktadır. 2021 Ocak ayı içine Türkiye'de 767 internet kullanıcısıyla çevrimiçi bir anket uygulaması gerçekleştirilmiştir. Üçüncü kişi etkisinin tespit edilmesinde bağımlı değişken $T$ testi ve üçüncü kişi etkisiyle ilgili değişkenlerin belirlenmesinde hiyerarşik regresyon analizi uygulanmıştır.Elde edilen sonuçlar, üçüncü kişi etkisinin sağlık konulu çevrimiçi mez/dezenformasyona ilişkin de geçerli olduğunu ve kişilerin dijital mez/dezenformasyonun tespit edilmesinde algıladıkları yetkinliklerinin ve dijital mez/dezenformasyona maruz kalma durumlarının üçüncü kişi etkisinin önemli yordayıcıları olduğunu göstermiştir.

Anahtar Kelimeler: Üçüncü Kişi Etkisi, Mezenformasyon, Dezenformasyon, Dijital Medya, Sağıı Haberleri

\author{
ASUMAN KUTLU \\ Dr. Öğr. Üyesi \\ Beykent Üniversitesi \\ asumank@beykent.edu.tr \\ ORCID ID: 0000-0003-2770-3008
}

JOURNAL OF SELÇUK COMMUNICATION 2021; 14(2): 514-528

doi: 10.18094/ JOSC.881441 


\section{INTRODUCTION}

Exploring the perceptual gap between self and other regarding media impacts, the third person effect theory relies on two principles. First, people are inclined to assess the effects of media to be greater on others than themselves. This comprises perceptual component of the assumption. The second principle is related to the behavioural component in which the perceptual gap may cause people to take action. The theory was coined by Davison (1983) and for the next few decades, TPE research predominantly has focused on comparison of different media types as well as moderators magnifying that perceptual bias. The emergence of new communication technologies has led scholars to turn their attention to research TPE in digital contexts and in recent years, research on TPE has gained more importance while judging media effects on oneself and others as mis/disinformation online has become a growing concern worldwide. The COVID-19 pandemic has increased health information-seeking online and amplified the problem of mis/disinformation as well. Infodemic, the blend of "information" and "epidemic" coined in 2003 during SARS outbreak, has seen renewed usage during COVID-19 (Words we're watching: "Infodemic", 2020). Although social media companies have claimed that they have addressed attempts to prevent the spread of COVID-19 infodemic, recent research has shown that they have failed to take action related to mis/disinformation. For instance social media posts directly threating public life are removed but the other ones including misleading information to constitute a less immediate threat are being left online (Social media firms fail to act on Covid-19 fake news, 2020). In addition, COVID-19 vaccines related mis/disinformation spreading widely on digital platforms is considered to threaten public health. Repeated exposure to mis/disinformation may increase the perceptual bias both in assessing the effect of factual information and mis/disinformation on self and others. Furthermore, perceived competence in detecting mis/disinformation can act as one of the key moderators affecting TPE. The main purpose of this article is to test TPE hypothesis in the context of health related mis/disinformation online. The first section provided an overview of the literature on TPE. The methodology section included sampling and data gathering process which was followed by the findings in the third section. The conclusion section discussed the results and highlighted the key points. 


\section{THIRD PERSON EFFECT}

The third-person effect introduced by Davison in a 1983 article, suggests that individuals have a tendency to perceive others to be more influenced by media messages than they are. He explained the third person effect through a historical incident of a service unit of African American troops with white officers in the Second World War. Having learnt their location, the Japanese disseminated propaganda leaflets warning the troops not to risk their life as they had no dispute with colored people. The next day, the unit was withdrawn feeling worried that black troops would be affected by propaganda brochures and would desert. As Davison explained "... I can't find any evidence that the propaganda had an effect on the troops at all. But it sure had an effect on the white officers. The leaflets seem to have caused a substantial reshuffle of personnel" (1983, pp. 1-2) Thus, TPE differs from media effect theories as it mainly deals with perceptions of media effects rather than direct influence of media on people. TPE addresses perceptual and behavioral components. While the perceptual component deals with the influence of media on the self and others, the behavioral component deals with how people's perceptions of media effects on others cause them to take preventive measures (Davison, 1983, p. 1; Perloff, 2002, p. 489).

The literature on TPE has demonstrated a broad perspective in exploring perceptual bias in several media contexts from news coverage (Cohen, Mutz, Price, \& Gunther, 1988; Price, Huang, \& Tewksbury, 1997; Hoffner, Buchanan, Anderson, Hubbs, \& Kamigaki, 1999; Li, 2015) and from advertising (Duck, Terry, \& Hogg, 1995; Huh, Delorme, \& Reid, 2004; Eisend, 2017) to online media (Banning \& Sweetser, 2007; Antonopoulos, Veglis, Gardikiotis, Kostakis, \& Kalliris, 2015; Çakır \& Çakır, 2012). Research has also explored conditions to magnify TPE. Much research has examined the level of social distance as a moderator in the context of TPE (Perloff, 1999, p. 364). Social distance refers to similarity between the self and the target other. Social distance evaluated by geographical distance, psychological distance or group participation are regarded to affect the level of TPE (Banning \& Sweetser, 2007, s. 454) and much research has proved that TPE increases with distance (Gibbon \& Durkin, 1995, p. 597; Cohen, Mutz, Price, \& Gunther, 1988, s. 161; Paek, Pan, Sun, Abisaid, \& Houden, 2005, p. 143) and the greater distance creates a greater TPE. As Davison noted regarding censor boards, "Even the censor's friends are usually safe from pollution. It is the general public that must be protected." (1983, 
p. 14) Media exposure (Hoffner, Buchanan, Anderson, Hubbs, \& Kamigaki, 1999, p. 726; Wei, Lo, \& Lu, 2008, p. 261; S,tefăniță, Corbu, \& Buturoiu, 2018, pp. 5-6; Liu \& Huang, 2020, p. 789) and knowledge of media content (Driscoll \& Salwen, 1997, p. 541; Chapin, 2002, p. 216; Wei, Lo, \& Lu, 2008, p. 261) have been considered as other key moderators affecting TPE. Previous studies have also supported source credibility in testing TPE hypothesis. That is, TPE increases depending on information channel. For instance, the third-person effect is greater for political advertising perceived as more biased than newspapers and television usually perceived to present a factual narrative. TPE decreases with the credibility of the source (Johansson, 2005, p. 83; Gunther, 1991, p. 355). Thus, people will likely to think that mis-and disinformation online will have a greater effect on others compared to factual information and may rely on their knowledge, perceived or real, in detecting of mis- and disinformation online when judging its effect on oneself and others.

A growing body of research has also pointed to the examination of digital disinformation in context of the third person effect. Indeed, PEW Research Center (Mitchell, Gottfried, Stocking, Walker, \& Fedeli, 2019) recently reported that at least half of the American respondents relied on their ability to recognize inaccurate information than the ability of broader public's ability to distinguish it. The findings demonstrated that people consider themselves more compatible in detecting misinformation than the others. In addition to TPE regarding perceived ability to spot fake news, the effect is greater when compared to ability of distant others than to close ones (Corbu, Oprea, Negrea-Busuioc, \& Radu, 2020, p. 165).

Another study conducted in 2018 confirmed perceived competence to detect disinformation hypothesis and also noted that TPE increased with people's increasing fake news exposure (Ș,tefăniță, Corbu, \& Buturoiu, pp. 5-6) Furthermore, social distance has also been proved to be a key variable to estimate TPE of digital disinformation. The study exploring the perceived effect of digital fake news on COVID-19 in China showed that respondents who practice more fact-checking perceive others to be likely more influenced by disinformation (Liu \& Huang, 2020, p. 789) Previous research also showed that TPE led to different ways to fight disinformation online. For instance people who had a greater level of TPE, tended to support media literacy approach rather than media regulation approach (Jang \& Kim, 2018, p. 295) On the other hand the study focusing on global warming and behavioural component of TPE found evidence of support for regulation on fake news (Hong, 2020, p. 1). 
Drawing on the previous literature discussed above, we addressed three issues, which are social distance, mis/disinformation exposure and perceived competency to detect mis/disinformation in context of TPE, and formulated the following hypotheses:

H1: Respondents will perceive digital mis/disinformation about health news to have greater effect on others than on themselves.

$\mathrm{H} 2$ : Perception of competency in detecting digital mis/disinformation will increase third-person effects.

H3: Exposure to digital mis/disinformation will increase third-person effects.

\section{METHODOLOGY}

\section{Survey Description}

A Turkish language questionnaire was developed based on previous studies carried out in the context of third-person effect. The survey consisted of two main sections: the first section was divided into three subsections and measured the variables to test hypothesized relationship. It consisted of four questions assessing TPE in regarding health related mis/disinformation online, one question for health related digital mis/disinformation exposure and three questions evaluating perceived competency in detecting mis/disinformation. The second section consisted of three questions asking for general demographics. Although there is a difference between misinformation and disinformation, we preferred to use mis/disinformation to address both types of false information. Besides, the research was carried during COVID-19 pandemic, we did not only refer to pandemic-related mis/disinformation because fear of Covid-19 may cause other patients with cancer or heart disease to decline their treatment (Hafner, 2020) as well as other people who have general health problems to stay home instead of receiving medical treatment. Hence, the digital media may offer billions of pages of health related information for those who do not leave their house to take treatment.

The whole questionnaire except general demographics used a 5-point Likert scale. The survey was conducted in January 2020, among people giving informed consent to participate in the survey. The study received the approval of the ethics committee of the researcher's university. A web survey through Google Forms was administered in January 2021 and was designed in a way that if respondents gave 
informed consent, they could participate in the survey. They were also provided information about the research and confidentiality of data before answering questions. It was piloted among 50 participants and revised based on the feedback received.

\section{Data Collection and Statistics}

The survey was administered in January, 2021. A random sample of 767 respondents were recruited for the web-survey. Eleven participants who refused to give informed consent were excluded from the sample. We also excluded six participants giving partial answers. So the final data set contained 767 respondents. The presumed effects of health-related mis/disinformation on the self and others were analyzed by using paired sample t-test. We also conducted hierarchical regression analysis to identify the factors associated with TPE. We performed statistical analyses using SPSS and tested the hypothesized relationships.

\section{RESULTS}

The final sample of respondents consisted of 767 respondents, with a prevalence of female gender $63 \%$. Twenty percent of the participants were between 18 and 24 years, \%38 were between 25 and 34 years, $\% 27$ were between $35-44$ years, $\% 12$ were 45 and 54 years, and $\% 3$ were 55 and above years of age. The age of respondents indicated a sample of young adults consistent with population of the country (Türkiye Nüfusu Yaş Gruplarına Göre Dağıımı 2019).

To test the first hypothesis proposing perceptual difference between the self and others regarding health related mis/disinformation online, we conducted a paired samples t-test to compare the scores for the self with the scores for others.

Table 1 Results of Perceived Effect of Health-Related Digital Mis/Disinformation on Self and on Others

\begin{tabular}{lll}
\hline & SELF & OTHERS \\
\hline Mean(SD) & 2.63 & 3,62 \\
$\mathrm{~N}$ & 767 & 767 \\
Std. Deviation & 0.87 & 0.82 \\
\hline
\end{tabular}

$t=645.53 \quad p<0.001 \quad$ Cohen's $d=1.18$

Table 1 indicated that the mean score for self is $2.63(\mathrm{SD}=0.87)$ while it is $3.62(\mathrm{SD}=0.82)$ for the others. The presumed differences between the self and the others regarding the effect of mis/disinformation were statistically significant ( $t=645.53, p<0.001$, Cohen's $d=1.18$ ). It is strongly 
evident that third person effect existed regarding health related mis/disinformation online. The first hypothesis is supported.

The second and third hypotheses proposed the impact of two variables which are perceived competency to detect mis/disinformation online and exposure to mis/disinformation. To test these hypotheses, we performed a hierarchical regression analysis with TPE as the dependent variable. The results of the analysis were reported in Table 2.

Table 2 Results of Hierarchical Regression Analysis of TPE Variables

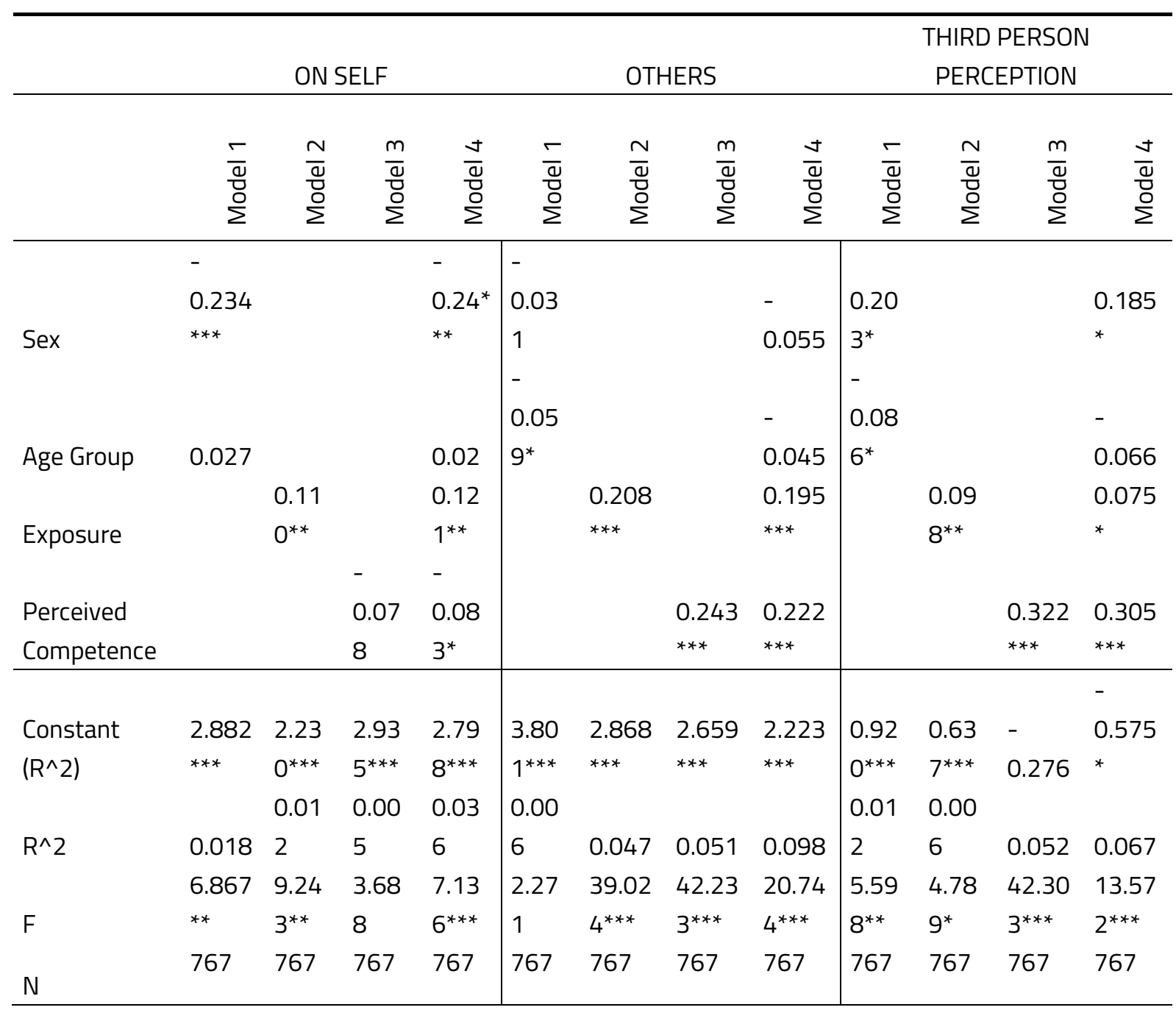

Perceived competence in detecting mis/disinformation online proved to be strong predictor of TPE $(\boldsymbol{\beta}=0.305, p<0.001)$. In addition, it was positively associated with presumed effects of mis/disinformation on others $(\boldsymbol{\beta}=0.222, p<0.001)$ and on self $(\boldsymbol{\beta}=-0.083, p<0.001)$. The results supported hypothesis $\mathrm{H} 2$. Table 2 also presented that exposure to digital mis/disinformation online was positively associated with TPE $(\boldsymbol{\beta}=0.075, \mathrm{p}<0.001)$. It was also positively associated with perceived 
effects of mis/disinformation on others $(\boldsymbol{\beta}=0.195, p<0.001)$ and on self $(\boldsymbol{\beta}=0.121, p<0.001)$ supporting Hypothesis H3.

Previous research has supported TPE hypothesis in several media contexts and the findings discussed below were broadly in line with them.

\section{Digital Mis/Disinformation and Third Person Effect}

Consistent with previous work suggesting people tend to assume that messages conveyed through media have greater impact on others than themselves (Davison, 1983, p. 1; Perloff, 1999, p. 364), findings proved that third person effects existed regarding health related mis/disinformation online. Not all people are aware of the difference between the words misinformation and disinformation but the terms are usually used to refer fake news broadly associated with biased information. When we consider mis/disinformation in the context of source credibility, the findings appeared to be consistent with previous work (Johansson, 2005, p. 83; Gunther, 1991, p. 355). The results also coincided with studies focusing on TPE in the context of health news (Wei, Lo, \& Lu, 2008, pp. 269-272), and digital disinformation (Liu \& Huang, 2020, pp. 790-792; St,efăniță, Corbu, \& Buturoiu, 2018, pp. 14-16; Hong, 2020, pp. 5-7). The findings exploring the perceptual component of the theory act as a starting point to further investigate the behavioural component including preventive actions to fight mis/disinformation.

\section{The Role of Perception of Competency to Detect Mis/Disinformation Online}

Our study added the dimension of perception of competency to detect digital mis/disinformation which may magnify TPE. According to a global report most people are confused about the credibility of media messages (Handley, 2018) and although some people find fake news easy to spot, it is still difficult for most of them (Santhanam, 2020). Not all people may react in the same way when they encounter mis/disinformation online. Some search information from a variety of sources and some use factchecking sites to verify information (Kutlu \& Doğan, 2020, pp. 94-96) The current study attempted to explore the perceived competency to detect mis/disinformation online on TPE rather than the impact of fact-checking behaviours on TPE as discussed in previous research (Liu \& Huang, 2020, p. 789). The findings suggest that perceived competence in detecting mis/disinformation online was found to be the strongest predictor affecting the intensity of TPE. People who perceived themselves as more competent to detect mis/disinformation were likely rate the impact greater on others. This may be because when 
they feel confident to spot mis/disinformation online, they tend to perceive others more digitally illiterate and more defenceless against it. Hence the perceived impacts get larger.

\section{The Role of Exposure to Mis/Disinformation}

Previous research has reported that media exposure amplifies self-other perceptual difference and indicated the more people were exposed to media messages, the stronger influence they tended to perceive on others (Hoffner, Buchanan, Anderson, Hubbs, \& Kamigaki, 1999, pp. 734-736; Wei, Lo, \& Lu, 2008, p. 270). Considering exposure to disinformation, previous research has revealed similar findings (S,tefăniță, Corbu, \& Buturoiu, 2018, p. 15). For instance, in a study focusing on TPE of disinformation in the context of Covid-19, disinformation exposure on MSNs was found to be linked to TPE although it was not associated with TPE on social media. Researchers explained the difference with fact-checking mechanism on social media (Liu \& Huang, 2020, p. 792). In this study, rather than comparing TPE in different digital channels, we aimed to explore the impact of digital mis/disinformation exposure (including all web based information channels, namely online news media and social media) on TPE and the findings showed it was positively associated with presumed effects of mis/disinformation on others and on the self. This may be because exposure leads to much awareness of digital mis/disinformation which serves as a magnifying impact on TPE in return. Besides exposure may cause people to develop fact-checking behaviour which seems very related to the role of perception of competency to detect mis/disinformation discussed in the previous section.

\section{CONCLUSIONS}

The main aim of this study was to explore health related mis/disinformation online in the context of TPE. Three hypotheses were tested with data provided through a web-based survey among 767 Turkish internet users. The results supported all hypotheses proposed. This research providing contribution to TPE within digital media can benefit other researchers exploring TPE in different media contexts. However, it has several limitations. First, the sample size was relatively small. Although results were broadly in line with previous studies, they cannot be generalized. Second, the survey was conducted in Turkish so the research sample did not include non-Turkish speaking internet users which constituted a relatively significant portion of the country population. Third, our study did not include some other key variables such as knowledge or media use and we only tested TPE in the context of 
health related mis/disinformation. Future studies may explore the role of mentioned moderators in the context of digital mis/disinformation in general or they may compare the presumed impact of misinformation and disinformation. To conclude, the third person effect theory is still considered an active research topic discussed in media studies and needs to be expanded considering the behavioural consequences of the presumed impact of digital media in future studies.

\section{GENIŞSLETILMiş öZET}

Davison'ın 1983 yılında yazdığı makalesinde literatüre kazandırdığı üçüncü kişi etkisi, insanların, medya mesajlarından diğer kişilerin daha fazla etkilendiklerini düşünme eğiliminde oldukları varsayımına dayanır. Bu nedenle algılanan medya etkilerine odaklanan üçüncü kişi etkisi, medyanın kişiler üzerindeki doğrudan etkisini araştıran medya etki teorilerinden farklı bir çerçevede ele alınmaktadır. Üçüncü kişi etkisi, algısal ve davranışsal olarak iki temel boyutta ele alınır. Algısal boyut, medyanın kişinin kendi ve diğerleri üzerindeki algılanan etkisine ilişkinken, davranışsal boyutu medya etkilerine yönelik algılamalar ve kişilerin geliştirdikleri davranışlar arasındaki ilişkiye odaklanır. Literatürde üçüncü kişi etkisi, haber içerikleri (Cohen, Mutz, Price, \& Gunther, 1988; Price, Huang, \& Tewksbury, 1997; Hoffner, Buchanan, Anderson, Hubbs, \& Kamigaki, 1999; Li, 2015) reklamcılık (Duck, Terry, \& Hogg, 1995; Huh, Delorme, \& Reid, 2004; Eisend, 2017) ve çevrimiçi medya (Banning \& Sweetser, 2007; Antonopoulos, Veglis, Gardikiotis, Kostakis, \& Kalliris, 2015; Çakır \& Çakır, 2012) başta olmak üzere algısal yanlılığı farklı iletişim mecralarında ve bu yanlıı̆̆ı artıran etkenleri tartışacak şekilde oldukça geniş bir yelpazede ele alınmıştır. Araştırmaların önemli bir bölümünde sosyal mesafe medyanın algılan etkisi üzerinde önemli bir değişken olarak ele alınmıştır (Perloff, 1999, p. 364) ve bu çalışmaların çoğunda kişilerin, diğerleriyle arasındaki fiziksel ve psikolojik mesafenin üçüncü kişi etkisini artırdığı ortaya koyulmuştur (Gibbon \& Durkin, 1995, p. 597; Cohen, Mutz, Price, \& Gunther, 1988, s. 161; Paek, Pan, Sun, Abisaid, \& Houden, 2005, p. 143). Medya kullanımı (Hoffner, Buchanan, Anderson, Hubbs, \& Kamigaki, 1999, p. 726; Wei, Lo, \& Lu, 2008, p. 261; Sțefăniță, Corbu, \& Buturoiu, 2018, pp. 5-6; Liu \& Huang, 2020, p. 789) ve medya içeriği hakkında bilgi sahibi olma (Driscoll \& Salwen, 1997, p. 541; Chapin, 2002, p. 216; Wei, Lo, \& Lu, 2008, p. 261) üçüncü kişi etkisi odaklı araştırmaların incelediği diğer değişkenlerdir. Gerçekleştirilen araştırmalar, üçüncü kişi hipotezinin sınanmasında kaynak güvenirliğinin ve mesajların iletildiği kanalın, etkinin derecesinin belirlenmesinde de önemli faktörler olduğunu göstermiş̧tir (Johansson, 2005, p. 83; Gunther, 1991, p. 355). 
Illgili literatürden hareketle, sosyal mesafe, mez/dezenformasyona maruz kalma ve mez/dezenformasyonun tespit edilmesinde algılanan yetkinlik üçüncü kişi etkisi bağlamında ele alınarak aşağıdaki hipotezler geliştirilmiştir:

H1: Kişiler, sağlık konulu dijital mez/dezenformasyonun diğerleri üzerinde kendilerinden daha fazla etkide bulunacağını düşünme eğilimindedir.

H2: Dijital mez/dezenformasyonun tespit edilmesinde algılanan yetkinlik üçüncü kişi etkisini artırmaktadır.

H3: Dijital mez/dezenformasyona maruz kalma üçüncü kişi etkisini artırmaktadır.

Literatürdeki çalışmalar incelenerek, sağlık konulu dijital mez/dezenformasyonu üçüncü kişi bağlamında ölçmeyi amaçlayan 10 soruluk Türkçe bir anket formu hazırlanmış ve Google Forms üzerinde erişime açılmıştır. 2021 yılının Ocak ayı içinde Türkiye'de yaşayan 767 gönüllü internet kullanıcısı ile anket uygulaması gerçekleştirilmiştir. Üçüncü kişi etkisinin tespit edilmesinde bağımlı değişken T testi ve değişkenler arasındaki ilişkilerin belirlenmesinde hiyerarşik regresyon analizi uygulanmıştır. Elde edilen sonuçlara göre çalışmanın bütün hipotezleri doğrulanmıştır. Literatürde yapılan çalışmaların (Davison, 1983, p. 1; Perloff, 2002, p. 489) sonuçlarıyla tutarlı olarak üçüncü kişi etkisinin sağlık konulu dijital mez/dezenformasyon için de geçerli olduğu görülmektedir. Çalışmanın ayrıca üçüncü kişi etkisini, kaynak güvenirliği ya da sağlık haberleri ve dijital dezenformasyon bağlamında ele alan literatürdeki araştırmalarla benzer bulgulara sahip olduğu görülmektedir. Ancak bu çalışma üçüncü kişi etkisinin algısal boyutuna yoğunlaşmaktadır, dolayısıyla dijital medyada üçüncü kişi etkisinin mez/dezenformasyona ilişkin geliştirilecek davranışların da araştıııması önem arz etmektedir. Bu çalışma ayrıca literatürdeki araştırmalardan farklı olarak kişilerin dijital mez/dezenformasyonun tespit etmede algıladıkları yetkinliklerini üçüncü kişi etkisini artıran bir değişken olarak ele almıştır ancak bu da algısal boyuta ilişkindir. Dijital mez/dezenformasyon küresel bir sorun haline gelmiştir ve özellikle sağlık konulu gerçek olmayan enformasyonun kamu sağlığını tehdit ettiği için tekil kullanııılar için de doğruluğunun teyit edilmesinin gerektiği bir alan haline gelmiş ve kişiler, enformasyonu farklı kaynaklardan araştırmak ya da haber doğrulma sitelerini kullanmak gibi farklı yöntemler uygulayabilmektedir. 
Çalışmadan elde edilen bulgular, kişilerin gerçek olmayan bilgiyi tespit edebildiklerine duydukları güven algısının, üçüncü kişi etkisini artıran en önemli değişken olduğunu göstermiştir. Bunun nedeni kişilerin mez/dezenformasyonun tespit edebildikleri duydukları güvenin, diğer kişileri gerçek olmayan enformasyona karşı dijital alanda daha bilgisiz ve daha savunmasız olarak algılama eğilimlerinin güçlenmesi olabilir. Bu nedenle algılanan medya etkisi artmaktadır. Son olarak dijital mez/dezenformasyona maruz kalma durumunun, üçüncü kişi etkisini artırdığı görülmektedir. Gerçek olmayan bilgiye maruz kalma, dijital medyada enformasyon kirliliğine ilişkin farkındalığı ve beraberinde diğerleri üzerindeki medya etkisinin daha büyük olacağı algısını da getirebilir. Buna ek olarak, kişiler gerçek olmayan bilgilere maruz kaldıkça, enformasyon doğrulama davranışları geliştirmekte, bu da beraberinde üçüncü kişi etkisini artıran diğer unsurla ilişkilendirilebilir.

Sonuç olarak, sınırlı bir örneklemden elde edilen bu çalışma sonuçlarının, üçüncü kişi teorisi ve dijital medya bağlamında yapılacak gelecekteki araştırmalar için bir kaynak sunacağını ümit ediyoruz. Bu çalışma üçüncü kişi etkisinin algısal boyutuna odaklanmış olup, yapılacak araştırmaların dijital medyanın kişiler üzerindeki algılanan etkisinin davranışsal boyutlarına odaklanarak, gerçek olmayan enformasyonla mücadelenin desteklenmesi için önemli sonuçlar ortaya çıkaracağını düşünüyoruz.

\section{KAYNAKÇA}

Antonopoulos, N., Veglis, A., Gardikiotis, A., Kostakis, R., \& Kalliris, G. (2015). Web third person effect in structural aspects of the information on media websites. Computers in Human Behaviour, 44, 48-58.

Banning, S. A., \& Sweetser, K. D. (2007). How much do they think it affects them and whom do they believe?: Comparing the third person effect and credibility of blogs and traditional media. Communication Quarterly, 55(4), 451-466.

Chapin, J. (2002). Third-person perception and school violence. Communication Research Reports, 19(3), 216-225.

Cohen, J., Mutz, D., Price, V., \& Gunther, A. (1988). Perceived impact of defamation: An experiment on third-person effects. The Public Opinion Quarterly, 52(2), 161-173. December 2, 2020 tarihinde http://www.jstor.org/stable/2749271 adresinden alındı

Corbu, N., Oprea, D., Negrea-Busuioc, E., \& Radu, L. (2020). "They can't fool me, but they can fool the others!" Third person effect and fake news detection. European Journal of Communication, 35(2), 165-180.

Çakır, V., \& Çakır, V. (2012). Üçüncü kişi etkisi teorisi bağlamında sosyal paylaşım sitelerinin kullanımı. Retrieved November 5, 2020, from 
https://www.researchgate.net/publication/292982219_UCUNCU_KISI_ETKISI_TEORISI_BAG LAMINDA_SOSYAL_PAYLASIM_SITELERININ_KULLANIMI

Davison, P. W. (1983). The third person effect in communication. Public Opinion Quarterly, 47(1), 1-15.

Driscoll, P. D., \& Salwen, M. B. (1997). Self-perceived knowledge of the O. J. Simpson Trial: Third-person perception and perceptions of guilt. Journalism \& Mass Communication Quarterly, 74(3), 541-556.

Duck, J., Terry, D., \& Hogg, M. (1995). The perceived influence of AIDS advertising: Third person effects in the context of positive media content. Basic and Applied Social Psychology, 17(3), 305-325.

Eisend, M. (2017). The third person effect in advertising: A meta-analysis. Journal of Advertising, 46(3), 377-394.

Gibbon, P., \& Durkin, K. (1995). The third person effect: Social distance and perceived media bias. European Journal of Social Psychology, 25(5), 597-602.

Gunther, A. (1991). What we think others think: Cause and consequence in the third-person effect. Communication Research, 18(3), 355-372.

Hafner, K. (2020). Fear of Covid-19 leads other patients to decline critical treatment. Retrieved November 2, 2020, from nytimes.com: https://www.nytimes.com/2020/05/25/health/coronaviruscancer-heart-treatment.html

Handley, L. (2018). Nearly 70 percent of people are worried about fake news as a "weapon", survey says. Retrieved November 23, 2020, from https://www.cnbc.com/2018/01/22/nearly-70percent-of-people-are-worried-about-fake-news-as-a-weapon-survey-says.html

Hoffner, C., Buchanan, M., Anderson, J. D., Hubbs, L. A., \& Kamigaki, S. K. (1999). Support for censorship of television violence: The role of the third-person effect and news exposure. Communication Research, 26(6), 726-742.

Hong, S. C. (2020). Presumed effects of "fake news" on the global warming discussion in a crosscultural context. Retrieved December 12, 2020, from https://www.mdpi.com/20711050/12/5/2123/htm

Huh, J., Delorme, D. E., \& Reid, L. N. (2004). The third person effect and its influence on behavioral outcomes in a product advertising context: The case of direct-to-consumer prescription drug advertising. Communication Research, 31(5), 568-599.

Jang, M. S., \& Kim, J. K. (2018). Third person effects of fake news: Fake news regulation and media literacy interventions. Computers in Human Behavior, 80, 295-302.

Johansson, B. (2005). The third-person effect. Retrieved December 2, 2020, from https://www.researchgate.net/publication/313779930_The_Third-Person_Effect

Kutlu, A., \& Doğan, E. (2020). Kesin bilgi, yayalım: Hakikat sonrası çağda yalan haberlere ilişkin Y kuşağının tutum ve davranışları. Akdeniz Iletişim Fakültesi Dergisi(34), 83-101.

$\mathrm{Li}, \mathrm{X}$. (2015). Time span pf news coverage as an antecedent of perceptual and behavioral components of third-person effect. Asian Journal of Communication, 25(2), 115-134. 
Liu, P., \& Huang, L. V. (2020). Digital disinformation about COVID-19 and the third-person effect: Examining the channel differences and emotional outcomes. Retrieved December 12, 2020, from

https://www.researchgate.net/publication/343487042_Digital_Disinformation_About_COVI D-19_and_the_Third-

Person_Effect_Examining_the_Channel_Differences_and_Negative_Emotional_Outcomes

Mitchell, A., Gottfried, J., Stocking, G., Walker, M., \& Fedeli, S. (2019, June 5). 3. Americans think made-up news and videos create more confusion than other types of misinformation. Retrieved December 2 , 2020, from Journalism.org: https://www.journalism.org/2019/06/05/3-americans-thinkmade-up-news-and-videos-create-more-confusion-than-other-types-of-misinformation/

Paek, H. J., Pan, Z., Sun, Y., Abisaid, J., \& Houden, D. (2005). The third-person perception as scoail judgement: An exploration of social distance and uncertainty in perceived effects of political attack ads. Communication Research, 32(2), 143-170.

Perloff, R. M. (1999). The third-person effect research: A critical review and syhthesis. Media Psychology, 1(4), 353-378.

Perloff, R. M. (2002). The third person effect. In J. Bryant, \& D. Zillmann (Eds.), Media effects: Advances in theory and research (pp. 489-506). New York: Routledge.

Price, V., Huang, L.-N., \& Tewksbury, D. (1997). Third person effects of news coverage: Orientations toward media. Journalism and Mass Communication Quarterly, 74(3), 525-540.

Santhanam, L. (2020). American voters worry they can't spot misleading information, poll finds. Retrieved November 23, 2020, from https://www.pbs.org/newshour/politics/social-mediadisinformation-leads-election-security-concerns-poll-finds

Social media firms fail to act on Covid-19 fake news. (2020, December 5). Retrieved 2020, from bbc.com: https://www.bbc.com/news/technology-52903680

S,tefăniță, O., Corbu, N., \& Buturoiu, R. (2018). Fake news and the third-person effect: They are more influenced than me and you. Journal of Media Research, 11(3(32)), 5-23.

Türkiye Nüfusu Yaş Gruplarına Göre Dağılımı 2019. (2019, November 2). Retrieved 2020, from nufusu.com: https://www.nufusu.com/turkiye-nufusu-yas-gruplari

Wei, R., Lo, V.-H., \& Lu, H.-Y. (2008). Third-person effect of health news exploring the relationship among media exposure, presumed media influence, and behavioral intentions. American Behavioral Scientist, 52(2), 261-277.

Words we're watching: 'Infodemic'. (2020, December 12). Retrieved from merriam-webster.com: https://www.merriam-webster.com/words-at-play/words-were-watching-infodemicmeaning 